\title{
ДОСЛІДЖЕННЯ ВЗАЄМОЗВ'ЯЗКУ ЕКОНОМІЧНОЇ БЕЗПЕКИ ЗАКЛАДІВ ГРОМАДСЬКОГО ХАРЧУВАННЯ ВІД ПРИЙНЯТТЯ УПРАВЛІНСЬКИХ РІШЕНЬ В УMOBAX COVID-19
}

\author{
INVESTIGATION OF THE RELATIONSHIP \\ OF ECONOMIC SECURITY OF CATERING \\ ESTABLISHMENTS FROM MAKING MANAGEMENT \\ DECISIONS IN CONDITIONS OF COVID-19
}

\author{
Лихолат Світлана Михайлівна \\ кандидат економічних наук, доцент, \\ Національний університет «Львівська політехніка» \\ ORCID: https://orcid.org/0000-0002-0517-6852 \\ Рискальчук Альона Олегівна \\ студентка, \\ Національний університет «Львівська політехніка» \\ ORCID: https://orcid.org/0000-0002-1012-9049 \\ Lykholat Svitlana, Ryskal'chuk Alyona \\ National University «Lviv Polytechnic»
}

\begin{abstract}
Метою статті є дослідження впливу управлінських рішень на діяльність закладів громадського харчування та їх рівень економічної безпеки в умовах COVID-19 з метою розвитку напрацьованого іміджу. Досліджено вплив управлінських рішень на складові імідж-технологій. В основу дослідження закладено набутий імідж підприємств. В залежності від початкового стану підприємства нами наведено комбінацію інструментів для управління іміджем. Рекомендації розробляються відповідно до можливостей закладу, його цільової аудиторії та географічного розташування. 3 використанням офріційних джерел наведено статистичний огляд галузі громадського харчування в Україні і Польщі. Відображено основні показники і їх зміну, яка є реакцією на економічні процеси в країні. Розглянуто проблеми, які виникли в наслідок пандемії COVID-19, а також, зважаючи на думки експертів обох країн, зроблено висновки стосовно того, як галузь громадського харчування адаптувалася до умов сьогодення і наскільки важлива підтримка держави для фрункціонування закладу за карантинних обмежень.
\end{abstract}

Ключові слова: економічна безпека підприємства, управлінські рішення, заклади громадського харчування (ЗГХ), COVID-19, імідж, громадське харчування Польщі і України.

Целью статьи является исследование влияния управленческих решений на деятельность заведений общественного питания и их уровень экономической безопасности в условиях COVID-19 с целью развития наработанного имиджа. Исследовано влияние управленческих решений на составляющие имидж-технологий. Исследование основано на приобретенном имидже предприятий. В зависимости от начального состояния предприятий нами предоставлено комбинацию инструментов для управления имиджем. Рекомендации разрабатываются в соответствии с возможностями учреждения, его целевой аудиторией и географическим расположением. С использованием официальных источников приведен статистический обзор индустрии общественного питания в Украине и Польше. Отражены основные показатели и их изменение, которое является реакцией на экономические процессы в стране. Рассмотрены проблемы, возникающие в связи с пандемией COVID-19, и, учитывая мнения экспертов из обеих стран, сделаны выводы, как индустрия общественного питания адаптировалась к текущим условиям и насколько важна государственная поддержка фрунционирования учреждения в условиях карантинных ограничений.

Ключевые слова: экономическая безопасность предприятия, управленческие решения, предприятия общественного питания, COVID-19, имидж, общественное питание в Польше и Украине.

The main purpose of the article is to study the impact of the management decisions on the activities of catering 
establishments and their level of economic security in terms of COVID-19 in order to develop the established image. It is established that despite the existing array of research, the issue of forming profitable activities of catering establishments remains unresolved and is complicated by specific business conditions. A review of literary sources is on selected topics, which was studied by both domestic and foreign scientists. The conformity of the components of economic security of restaurant establishments to their image is considered. The influence of managerial decisions on the components of image technologies is investigated. The study is based on the acquired image of catering companies in Ukraine and Poland. Depending on the initial state of the enterprise, we provide a combination of tools for image management. The recommendations are developed in accordance with the capabilities of the institution, its target audience and geographical location. A statistical overview of the catering industry in Ukraine and Poland is provided, using official sources. The main indicators and their change, which is a reaction to economic processes in the country, are reflected. The problems caused by the COVID-19 pandemic are considered, and, based on the opinions of experts from both countries, conclusions are made about how the catering industry has adapted to today's conditions and how important is state support for the operation of the institution under quarantine restrictions. In the conclusion of the research the obtained results are substantiated and it is established that the difficult situation of public catering establishments is formed as a result of unsuccessful, untimely and incorrect administrative decisions in the past. Thus, catering establishments in Ukraine and Poland have great opportunities for development even in such a difficult time, but they need creative and thoughtful solutions that can minimize threats and increase the level of economic security of the institution.

Keywords: economic security of the enterprise, management decisions, public catering enterprises of Ukraine and Poland, COVID-19, image.

Постановка проблеми. У зв'язку з останніми подіями - пандемія COVID-19 та запровадження карантину, багато галузей потрапили в зону складних обставин і нових умов, які ускладнюють їх фрункціонування. До переліку цих галузей належить і громадське харчування. Частина підприємства вищезгаданої галузі припинила своє існування, але одночасно ті, що продовжують свою діяльність знаходяться в загрозливій ситуації або на межі банкрутства. Такі обставини знижують рівень економічної безпеки ЗГХ. Отже, для прийняття правильних управлінських рішень потрібно зважити всі загрози і ризики, які впливають на діяльність підприємств громадського харчування. Управлінські рішення мають призводити до зниження можливості настання банкрутства і прийматися з урахуванням можливостей сучасних технологій. Вдалі управлінські рішення зможуть підвищити рівень економічної безпеки ЗГХ, а також національної безпеки всієї країни завдяки використанню вже напрацьованого іміджу.

Аналіз останніх досліджень і публікацій. Економічна безпека $€$ важливим поняттям як на світовому рівні, так і на регіональному. Багато вітчизняних та зарубіжних науковців займалися вивченням даною теми, зокрема, Малишко В. М. [1], Козаченко Г.В.[2], Бінко І.Ф. [3], Ареф'єва О. В. [4], Єрмошенко М. М. [5], Шлемко В. Т. [6], Стеценко С. П. [7] та інших. Досліджуючи питання управлінських рішень Королев Ю. В. стверджує, що «управлінське рішення - це результат творчого цілеспрямованого аналізу проблемної ситуації, вибору шляхів, методів і засобів ії̈ вирішення у відповідності з ціллю системи менеджменту» [8]. Управлінським рішенням притаманна загальна властивість поліморфізму. Вони мають високий рівень складності, що пов'язано $з$ їх ключовою роллю і згаданою вище властивістю, а також мають певний перелік етапів, які коригуються відповідно до розробленого плану, але не відхиляються від загального процесу прийняття рішень [9].

Отже, управлінські рішення - це вибір 3 безлічі варіантів найоптимальнішого, який буде задовольняти індивідуальні потреби. Вагома роль у прийнятті рішень належить керівнику, його досвіду, принципам і цілям які прагне досягнути. Швидкість прийняття управлінських рішень і їх актуальність безпосередньо впливають на економічну безпеку закладу, галузі і країни загалом.

Звертаючись до трактування Шлемко В. Т. та Бінько І. Ф. «економічна безпека - це такий стан національної економіки, який дає змогу зберігати стійкість до внутрішніх і зовнішніх загроз і здатний задовольнити потреби особи, сім'ї, суспільства, держави» [10]. Водночас Фень К. С. вважає, що це стан підприємства «...при якому забезпечується стабільність його фрункціонування, фрінансову рівновагу і регулярне одержання прибутку, можливість виконання поставлених цілей і завдань» [12]. Зважаючи, на різницю визначень і тверджень важливим $€$ розуміння галузі в якій досліджується економічна безпека, а тому за належне вважаємо навести твердження Поповича В.С., який трактує економічну безпеку в розрізі окремих підприємств, як «комплексну систему забезпечення і захисту його економіч- 
них інтересів від внутрішніх і зовнішніх загроз, створювану і регульовану шляхом здійснення комплексу заходів, спрямованих на підтримку стійкості фрункціонування і можливості розвитку підприємства як незалежного господарюючого суб'єкта» [11].

Отже, управлінські рішення здійснюють значний вплив на рівень економічної безпеки, це підтверджено багатьма дослідженнями. А тому керівники і менеджери мають відповідально ставитися навіть до незначних змін і шукати максимально ефективні можливості реалізації прийнятих рішень.

Формулювання цілей статті (постановка завдання). Метою статті $€$ доведення впливу прийнятих управлінських рішень в умовах COVID-19 на рівень економічної безпеки закладів громадського харчування України та Польщі.
Виклад основного матеріалу. В умовах карантинних обмежень пов'язаних з COVID-19, заклади громадського харчування (ЗГХ) України та Польщі змушені функціонувати при нестандартних умовах. ЗГХ обох країн перебувають в скрутній ситуації і постійно здійснюють пошук ефективних управлінських рішень. Прогнозування розвитку ЗГХ стає нелегкою задачею через нові виклики спричинені розповсюдженням коронавірусної інфрекції. Проте, в даних умовах важливого значення набувають креативні і вміло спрогнозовані управлінські рішення, які базуються на використанні вже набутого підприємством іміджу.

Імідж являє собою систему соціального програмування поведінки суб'єктів і використання ментальних стереотипів і символів групової поведінки, вміле використання яких може покращити рівень економічної безпеки підприємства [13].

Таблиця 1

Відповідність складових економічної безпеки ЗГХ їх іміджу

\begin{tabular}{|c|c|c|}
\hline $\begin{array}{l}\text { Складові } \\
\text { економічної } \\
\text { безпеки }\end{array}$ & $\begin{array}{l}\text { Елементи } \\
\text { іміджу }\end{array}$ & Елементи впливу \\
\hline $\begin{array}{l}\text { Інтелектуальна } \\
\text { та кадрова }\end{array}$ & Внутрішній імідж & $\begin{array}{l}\text { Рівень професіоналізму, кваліфрікації і мотивації } \\
\text { персоналу; рівень управлінських рішень; система підбору } \\
\text { і навчання персоналу; система внутрішніх комунікацій; } \\
\text { оцінка роботи персоналу за критеріями }\end{array}$ \\
\hline Інтерфрейсна & $\begin{array}{l}\text { Бізнес-імідж, } \\
\text { візуальний імідж }\end{array}$ & $\begin{array}{l}\text { Рівень лояльності споживачів, стабільності фрінансового } \\
\text { положення; досвід роботи в галузі; ділова репутація } \\
\text { підприємства; логотип, зовнішній вигляд приміщення, } \\
\text { розроблення оголошень }\end{array}$ \\
\hline Соціальна & Зовнішній імідж & $\begin{array}{l}\text { Рівень співпраці з громадськими організаціями, } \\
\text { соцмережами, рівень РR-заходів; особливості вербальної } \\
\text { і невербальної поведінки персоналу }\end{array}$ \\
\hline Фінансова & Бізнес-імідж & $\begin{array}{l}\text { Рівень ділової активності, стабільність зав'язків } 3 \\
\text { економічними контрагентами, дотримання етичних норм } \\
\text { бізнесу, цінова політика організації }\end{array}$ \\
\hline Інформаційна & Внутрішній імідж & $\begin{array}{l}\text { Рівень поінформованості контактних груп, наявність } \\
\text { інфрормації в ЗМІ, рівень корпоративної культури компанії, } \\
\text { участь у громадських заходах }\end{array}$ \\
\hline Юридична & $\begin{array}{l}\text { Бізнес-імідж } \\
\text { організаційної } \\
\text { культури }\end{array}$ & $\begin{array}{l}\text { Рівень законослухняності підприємства, стабільність } \\
\text { зав'язків з економічними контрагентами, ділова } \\
\text { репутація, показники ділової репутації }\end{array}$ \\
\hline Ринкова & Імідж керівника & $\begin{array}{l}\text { Рівень позиціонування підприємства на ринку, } \\
\text { продресіоналізму персоналу і керівництва, система } \\
\text { управління персоналом, рівень комунікації між різними } \\
\text { ланками управлінців, HR-бренд підприємства }\end{array}$ \\
\hline Технологічна & $\begin{array}{l}\text { Кадровий імідж, } \\
\text { імідж товару }\end{array}$ & $\begin{array}{l}\text { Рівень якості товару, професіоналізму персоналу і } \\
\text { технології виробництва, компетентність, мобільність, } \\
\text { організованість працівників; рівень імідж-технологій; } \\
\text { фрірмовий стиль, додаткові атрибути товару }\end{array}$ \\
\hline $\begin{array}{l}\text { Екологічна та } \\
\text { енергетична }\end{array}$ & $\begin{array}{l}\text { Еколого- } \\
\text { енергетичний } \\
\text { імідж }\end{array}$ & $\begin{array}{l}\text { Дотримання стандартів якості, екологізації процесів; } \\
\text { впровадження соціально-екологічних заходів; } \\
\text { використання альтернативних джерел, утилізація } \\
\text { відходів, підтримка національних соціальних проектів }\end{array}$ \\
\hline
\end{tabular}


Імідж виступає базою для форомування імідж-технологій, і як наслідок сприяє аналізу інсормації, яка пов'язана з фрормуванням економічної безпеки ЗГХ. Кожна складова імідж-технологій перебуває під впливом управлінських рішень і залежить від об'єму задіюваних ресурсів. У таблиці 1 наведено відповідність складових економічної безпеки ЗГХ їх іміджу.

На нашу думку, особливе місце належить технологічній, інтелектуальній та кадровій складовим економічної безпеки, які реалізуються через відповідні елементи іміджу таких як кадровий імідж, імідж товару, внутрішній імідж відповідно.

Використовуючи офріційні джерела ними здійснено статистичний огляд галузі громадського харчування України та Польщі. Основні тенденції були побудовані за даними Державної служби статистики України та Державної служби статистики Польщі (табл. 2) [17; 18].

Варто зауважити, що сорера громадського харчування з початком пандемії постраждала чи не найбільше. Підтвердженням цьому $\epsilon$ думка аналітиків. Зокрема, відповідно до інфрормації ADASTRA.org «... масштаби доставки їжі збільшились близько на 25\%, однак це все ж не змогло перекрити збитки рестораторів...» [19]. Тоді як через зростання кількості безробітних під час карантину, багато громадян 3 метою економії коштів почали надавити перевагу домашній кухні, хоча раніше типовим для них було харчування в барах, кафе і ресторанах. Після послаблення карантину близько 86\% ЗГХ України поновили роботу, однак значна кількість закладів збанкрутували і не змогли чинити опір обставинам, що склалися [20]. Згідно 3 даними POSbistro, основна частина ресторанів Польщі також були закриті після введення карантинних обмежень. Однак доставка їжі продовжували здійснювати, і кількість ЗГХ 3 доставкою їжі скоротилася лише на 10\%. За період карантину доходи ЗГХ Польщі скоротилася в середньому на 60\%. Варто зауважити, що навіть після незначних послаблень лише $20 \%$ гостей повернулися до ресторанів, пабів і кав'ярень. Проте, доходи залишалися низькими і галузь перебувала на межі банкрутства, але завдяки переговорам щодо орендної плати, призупинення сплати внесків на соціальне страхування та іншим діям влади і місцевих органів самоврядування ситуація в Польщі нормалізувалася [21].

Згідно даних осріційних джерел України та Польщі можна зробити висновок, що кількість ЗГХ за період 2010-2019 років залишалася практично незмінною. Водночас в Україні спостерігалися більш вагомі зміни, що може бути пов'язано з рівнем соціально-економічного розвитку досліджуваних країн, а також з рівнем політичної стабільності. Досліджуючи сукупні доходи галузі ми бачимо аналогічну ситуацію [23].

Взявши до уваги опитування Української ресторанної асоціації, можна сказати, що 2020 рік був важким для 3ГХ тому що, майже кожен четвертий заклад працював лише на літніх терасах і лише близько 16\% закладів здійснювали одночасно доставку страв і обслуговування гостей на терасі та в залі. $11 \%$ закладів були повністю закриті. Не менш важливим $€$ питання прибутку, стосовно якого респонденти зазначили, що у $24 \%$ опитаних

Показники діяльності суб'єктів ресторанного бізнесу в Україні та Польщі

\begin{tabular}{|c|c|c|c|c|c|c|c|c|}
\hline \multirow[t]{2}{*}{ 丞 } & \multicolumn{2}{|c|}{$\begin{array}{l}\text { Кількість закладів } \\
\text { ресторанного } \\
\text { господарства }\end{array}$} & \multicolumn{2}{|c|}{$\begin{array}{c}\text { Зміна кількості } \\
\text { закладів } \\
\text { ресторанного } \\
\text { господарства }\end{array}$} & \multicolumn{2}{|c|}{$\begin{array}{c}\text { Сукупні доходи } \\
\text { галузі } \\
\text { (поточні ціни), } \\
\text { млн. дол. США }\end{array}$} & \multicolumn{2}{|c|}{$\begin{array}{c}\text { Зміна сукупного } \\
\text { доходу, } \\
\%\end{array}$} \\
\hline & Польща & Україна & Польща & Україна & Польща & Україна & Польща & Україна \\
\hline 2010 & 70483 & 39920 & - & - & 8228,77 & 2315,65 & - & - \\
\hline 2011 & 67356 & 33186 & $-4,44$ & $-16,87$ & 8372,88 & 2340,45 & $+1,75$ & $+1,07$ \\
\hline 2012 & 68787 & 37351 & $+2,12$ & $+12,55$ & 10098,80 & 4045,35 & $+20,61$ & $+72,84$ \\
\hline 2013 & 66966 & 43612 & $-2,65$ & $+16,76$ & 9552,63 & 5168,92 & $-5,41$ & $+27,77$ \\
\hline 2014 & 66345 & 49447 & $-0,93$ & $+13,38$ & 8266,90 & 3183,49 & $-13,46$ & $-38,41$ \\
\hline 2015 & 68342 & 50381 & $+3,01$ & $+1,89$ & 5420,92 & 2066,87 & $-34,43$ & $-35,08$ \\
\hline 2016 & 69414 & 50176 & $+1,57$ & $-0,41$ & 5420,38 & 2291,51 & $-0,01$ & $+10,87$ \\
\hline 2017 & 70108 & 49950 & $+1,00$ & $-0,45$ & 5551,06 & 1493,03 & $+2,41$ & $-34,84$ \\
\hline 2018 & 69829 & 53558 & $-0,40$ & $+7,22$ & 5720,63 & 1942,37 & $+3,05$ & $+30,10$ \\
\hline 2019 & 72355 & 60851 & $+3,62$ & $+13,62$ & 7530,18 & 2883,02 & $+31,63$ & $+48,43$ \\
\hline 2020 & 52568 & 42686 & $-27,35$ & $-29,85$ & 3550,63 & 459,18 & $-52,85$ & $-84,07$ \\
\hline
\end{tabular}




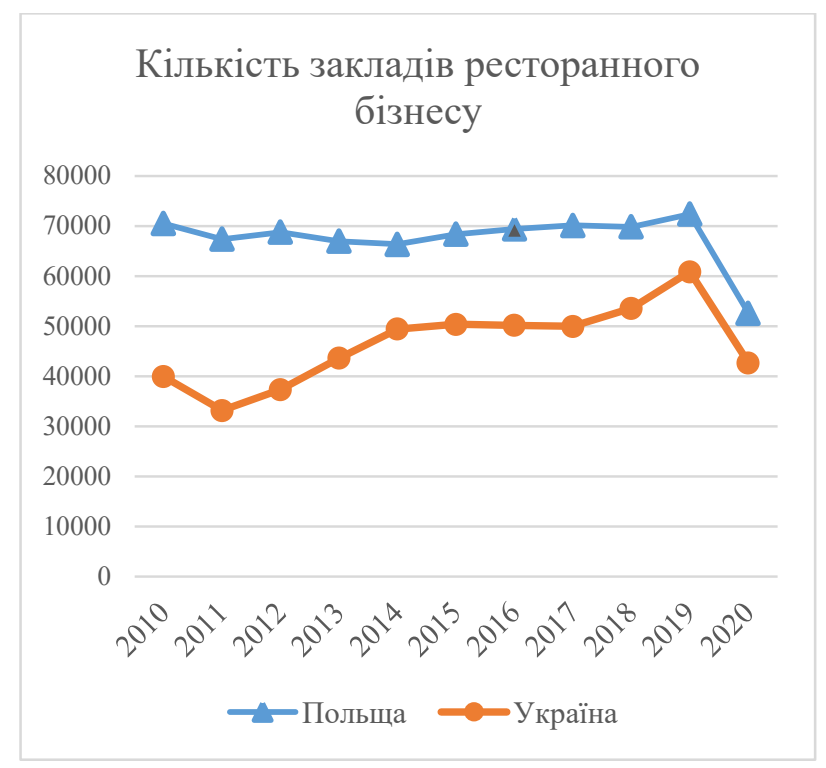

Рис. 1. Кількість закладів

ресторанного бізнесу в Польщі та Україні, 2010-2020 pp.

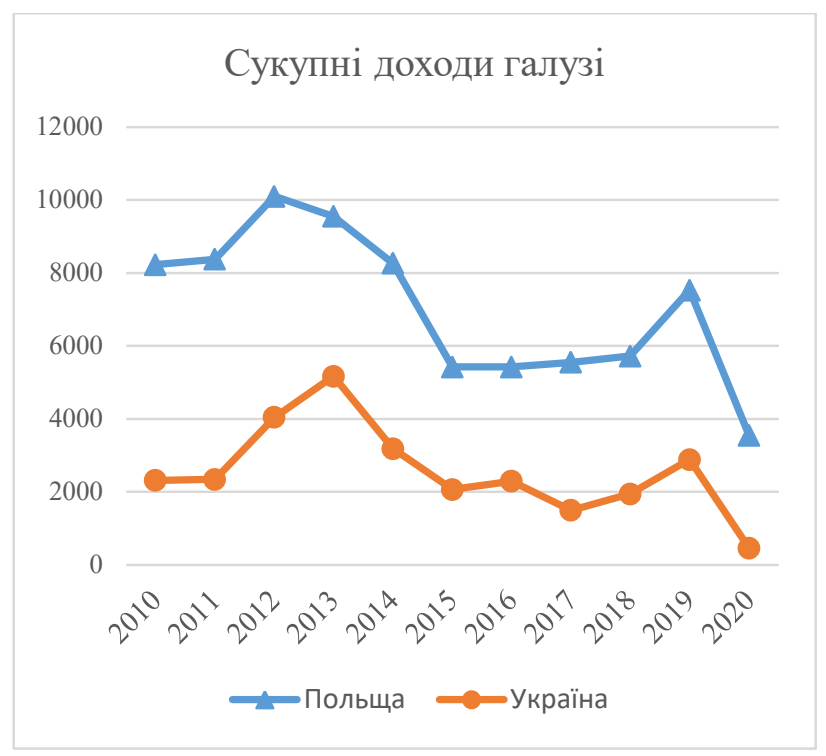

Рис. 2. Роздрібний товарооборот закладів ресторанного бізнесу в Польщі та Україні, 2010-2020 pp.

Джерело: побудовано авторами за джерелом [22]

він становив менше 20\% порівняно з аналогічним періодом минулого року, від 21 до 40\% отримали 24\% закладів, 41-60\% виручки тримали 19\% підприємців і лише 8\% 3 тих хто брав участь в опитуванні зазначили, що значних змін не відбулося і він становив близько 81\% [24]. Якщо аналізувати галузь громадського харчування Польщі то, за словами президента FOR Solutions ринок змінився до невпізнання і очистився від ресторанів, які були нестабільні в даному бізнесі. Як і в усьому світі ресторани у країні були закриті або їх робота була частково обмежена.

Водночас, багато ЗГХ стали отримувати прибуток за рахунок доставки. Проте, основною проблемою вишуканих страв $€$ порушення подачі, оскільки для багатьох 3 них важлива температура подачі, атмоссрера їжі і ії візуальна подача, що є неможливим за умов доставки. До 2019 року включно ЗГХ України та Польща мали власні сценарії розвитку. Але у зв'язку з COVID-19, як в Україні, так і в Польщі спостерігається різке скорочення кількості ЗГХ (в Україні на - 29,85\%, в Польщі на $27,35 \%$ ) у порівнянні з 2019 роком, а також скорочення сукупного доходу ресторанів, кафре, пабів (в Польщі на - 52,85\%, в Україні на - 84,07\%). Після кризи 2014 року український ресторанний бізнес почав відновлюватися і приносити значно більші прибутки ніж до цього. У 2019 порівняно з 2014 кількість ЗГХ зросла на +10871, а товарооборот у 2019 зріс у 1,9 рази, порівняно з 2014 і 3,7 рази порів- няно з 2010 роком. Однак, такі зміни пов'язані з загальним зростанням рівня цін, при майже незмінній кількості відвідувачів.

В межах дослідження було здійснено SWOTаналіз ЗГХ який показав, що спостерігається подібність загроз і можливостей для закладів обох країн, проте, є і певні відмінності. Встановлено, що багато загроз $є$ актуальними для обох країн, наприклад, недобросовісна конкуренція, зниження купівельної спроможності населення тощо. Але основною загрозою прибуткового фрункціонування ЗГХ стала пандемія COVID-19. У зв'язку з новими умовами функціонування ЗГХ змушені шукати альтернативні рішення, адже прийняті в «спокійний» час управлінські рішення виявляються неактуальними. Відповідно до SWOT-аналізу серед можливостей для ЗГХ України та Польщі існує потреба у державній підтримці. Водночас, самостійний розвиток або підтримка власного бренду (іміджу) теж важливо. Такі дії потрібні для утримання вже наявної цільової аудиторії та залучення нових клієнтів. В будь-якому разі кожне управлінське рішення має свої наслідки через що менеджери повинні аналізувати сильні і слабкі сторони не лише локально, але і в межах держави.

Висновки. В умовах карантинних обмежень пов'язаних з COVID-19 умови господарювання ЗГХ стали нестандартними. Проте, скрутне становище $є$ наслідком невчасно прийнятих управлінських рішень. Встановлено, що ЗГХ різних країн маючи однакові можливості не можуть однаково адаптуватися до 
нових викликів сьогодення. Обґрунтовано, що економічна безпека ЗГХ залежить і від впливу COVID-19, а не лише від зовнішніх загальновідомих фракторів, як вважалося до цього. Можна стверджувати, що з пандемією Covid-19 ситуація для всіх галузей економіки
України та Польщі стала складною, і ЗГХ не залишилися абстрагованими. Проте, своєчасні управлінські рішення і відповідні іміджтехнології, які можна реалізувати, стають для певних закладів можливістю, а для певних навпаки новою загрозою.

\section{СПИСОК ВИКОРИСТАНИХ ДЖЕРЕЛ:}

1. Малишко В.М. Актуальні проблеми економічної безпеки в системі національної безпеки України. Юридичний вісник. Повітряне і космічне право. 2015. № 4. С. 129-133.

2. Козаченко Г.В., Пономарьов В.П., Ляшенко О.М. Економічна безпека підприємства: сутність та механізм забезпечення : монограсрія. Київ : Лібра, 2003. 280 с.

3. Бинько И.Ф., Шлемко В.Т. Как обеспечить экономическую безопасность Украины. Всеукраинские ведомости. 1997. № 138(810). С. 3-8.

4. Арєфр'єва О.В., Кузенко Т.Б. Планування економічної безпеки підприємств. Київ : Вид-во Європ. ун-ту, 2004. $170 \mathrm{c}$.

5. Єрмошенко М.М. Фінансова безпека держави: національні інтереси, реальні загрози стратегія забезпечення. Київ : КТНЕУ, 2001. 309 с.

6. Шлемко В.Т., Бінько І.Ф. Економічна безпека України: сутність і напрямки забезпечення : монограсія. Київ : НІСД, 1997. 144 с.

7. Стеценко С.П. Економічна безпека: сутність і структура. Інвестиції: практика та досвід. 2013. № 24. C. 104-106.

8. Королев Ю.Б., Коротнев В.Д., Кочетова Г.Н. и др. Менеджмент в АПК. Москва : Колос С, 2007. 424 с.

9. Ткачук В.В. Розвиток інноваційних процесів управління в сучасних умовах господарювання. Вісник Кам'янець-Подільського національного університету імені Івана Огієнка. Економічні науки. 2012. № 6. C. 179-182. URL: http://nbuv.gov.ua/UJRN/vkpnuen_2012_6_44 (дата звернення: 27.06.2021).

10. Шлемко В.Т., Бінько І.Ф. Економічна безпека України: сутність і напрямки забезпечення. Київ : НІСД, 1997. $144 \mathrm{C}$.

11.Половнев К.С. Механизм обеспечения экономической безопасности промышленного предприятия : автореф. дисс. на соискание учен. степени канд. экон. наук. Екатеринбург, 2002. 34 с.

12. Фень К.С. Розвиток економічної безпеки в Україні. Теоретико-методологічні і науково-практичні засади інвестиційного, фінансового та облікового забезпечення розвитку економіки. МНП Інтернет-конференція Подільського державного аграрно-технічного університету. 2013. С. 57-61.

13. Федоров И.А. Имидж как программирование поведения людей. Рязань : Новое время, 1997. 240 с.

14. Маркин В.М. «Я» как личностная характеристика госуда-рственного служащего. Москва : Имидж гос. Службы, 1996. С. 12-19.

15. Козаченко А.В., Пономарьов А.В., Лященко А.Н. Економічна безпека підприємства. Сутність і механізми забезпечення : монографія. Київ : Лібра, 2003. 280 с.

16. Іванова Т.М., Заїчковський А.О. Економічна безпека підприємства : навч. посіб. Київ : Центр учбової літератури, 2009. 256 с.

17.Державна служба статистики. URL: http://www.ukrstat.gov.ua/operativ/oper_new.html (дата звернення: 20.03.2021).

18. Торгово-промислова палата України. URL: https://ucci.org.ua/uploads/files/602f9ce03135f554471158.pdf (дата звернення: 27.06.2021).

19. Вплив COVID-19 та карантинних обмежень на економіку України. URL: https://www.kas.de/documents/ 270026/8703904/\%D0\%92\%D0\%BF\%D0\% (дата звернення: 27.06.2021).

20. COVID-19 - co zmienił w gastronomii? URL: https://smazymy.com/covid-19-co-zmienil-w-gastronomii/ (дата звернення: 27.06.2021).

21.Державна служба статистики. URL: http://www.ukrstat.gov.ua/operativ/oper_new.html (дата звернення: 27.06.2021).

22. Główny Urząd Statystyczny. URL: https://stat.gov.pl/obszary-tematyczne/roczniki-statystyczne/ (дата звернення: 27.06.2021).

23. W 2020 r. przybyło lokali gastronomicznych. URL: https://www.horecatrends.pl/gastronomia/114/w_2020_r przybylo_lokali_gastronomicznych,6513.html\#: :text=Z\%20czego\%20trwale\%20zbankrutowa\%C5\%820\%20 i,si\%C4\%99\%20na\%2085\%2C5\%20tys (дата звернення: 27.06.2021). 
24.Центр прикладних досліджень. Вплив Covid-19 на економіку України. URL: https://cpd.com.ua/vplyvCOVID-19-na-ekonomiku-Ukrainy.pdf (дата звернення: 27.06.2021).

25. Jaki wpływ na gastronomię może mieć koronawirus? URL: https://posbistro.com/blog/pl/jaki-wplyw-nagastronomie-moze-miec-koronawirus/ (дата звернення: 27.06.2021).

\section{REFERENCES:}

1. Malyshko V.M. (2015) Aktualni problemy ekonomichnoi bezpeky v systemi natsionalnoi bezpeky Ukrainy. Yurydychnyi visnyk. Povitriane i kosmichne pravo, no. 4, pp. 129-133.

2. Kozachenko H.V., \& Ponomarov V.P., Liashenko O.M. (2003) Ekonomichna bezpeka pidpryiemstva: sutnist ta mekhanizm zabezpechennia: monohrafiia. Kyiv: Libra, 280 p.

3. Binko I.F., \& Shlemko V.T. (1997) Kak obespechit ekonomicheskuyu bezopasnost Ukrainyi. Vseukrainskie vedomosti, no. 138(810), pp. 3-8.

4. Ariefieva O.V., \& Kuzenko T.B. (2004) Planuvannia ekonomichnoi bezpeky pidpryiemstv. Kyiv: Vyd-vo Yevrop. un-tu, $170 \mathrm{p}$.

5. Yermoshenko M.M. (2001) Finansova bezpeka derzhavy: natsionalni interesy, realni zahrozy stratehiia zabezpechennia. Kyiv: KTNEU, 309 p.

6. Shlemko V.T., \& Binko I.F. (1997) Ekonomichna bezpeka Ukrainy: sutnist i napriamky zabezpechennia: monohrafiia. Kyiv: NISD, $144 \mathrm{p}$.

7. Stetsenko, S.P. (2013) "Economic security: essence and structure". Investytsii: praktyka ta dosvid, no. 24, pp. 104-106.

8. Korolev Yu.B., Korotnev V.D., Kochetova H.N. y dr. (2007) Menedzhment v APK. Moscow: Kolos S, 424 p.

9. Tkachuk V.V. (2012) Rozvytok innovatsiinykh protsesiv upravlinnia v suchasnykh umovakh hospodariuvannia. Visnyk Kamianets-Podilskoho natsionalnoho universytetu imeni Ivana Ohiienka. Ekonomichni nauky, no. 6, pp. 179-182. Retrieved from: http://nbuv.gov.ua/UJRN/vkpnuen_2012_6_44 (accessed 27 June 2021).

10. Shlemko V.T., \& Binko I.F. (1997) Ekonomichna bezpeka Ukrainy: sutnist i napriamky zabezpechennia. Kyiv: NISD, $144 \mathrm{p}$.

11. Polovnev K.S. (2002) Mehanizm obespecheniya ekonomicheskoy bezopasnosti promyishlennogo predpriyatiya: avtoref. diss. na soiskanie uchen. stepeni kand. ekon. nauk. Ekaterinburg, 34 p.

12. Fen K.S. (2013) Rozvytok ekonomichnoi bezpeky v Ukraini. Teoretyko-metodolohichni i naukovo-praktychni zasady investytsiinoho, finansovoho ta oblikovoho zabezpechennia rozvytku ekonomiky. Mizhnarodna naukovo-praktychna Internet-konferentsiia Podilskoho derzhavnoho ahrarno-tekhnichnoho universytetu, pp. 57-61.

13. Fedorov I.A. (1997) Imidzh kak programmirovanie povedeniya lyudey. Riazan: Novoe vremya, 240 p.

14. Markin V.M. (1996) «Ya» kak lichnostnaya harakteristika gosuda-rstvennogo sluzhaschego. Moscow: Imidzh gos. sluzhbyi, pp. 12-19.

15. Kozachenko A.V., Ponomarov A.V., Liashchenko A.N. (2003) Ekonomichna bezpeka pidpryiemstva. Sutnist $i$ mekhanizmy zabezpechennia: monohrafiia. Kyiv: Libra, 280 p.

16. Ivanova T.M., \& Zaichkovskyi A.O. (2009) Ekonomichna bezpeka pidpryiemstva: navch. posib. Kyiv: Tsentr uchbovoi literatury, $256 \mathrm{p}$.

17. Derzhavna sluzhba statystyky. Retrieved from: http://www.ukrstat.gov.ua/operativ/oper_new.html (accessed 23 June 2021).

18. Torhovo-promyslova palata Ukrainy. Retrieved from: https://ucci.org.ua/uploads/files/602f9ce03135f5544 71158.pdf (accessed 20 June 2021).

19. Vplyv COVID-19 ta karantynnykh obmezhen na ekonomiku Ukrainy. Retrieved from: https://www.kas.de/ documents/270026/8703904/\%D0\%92\%D0\%BF\%D0\% (accessed 23 June 2021).

20. COVID-19 - co zmienił w gastronomii? Retrieved from: https://smazymy.com/covid-19-co-zmienil-w-gastronomii/ (accessed 23 June 2021).

21. Derzhavna sluzhba statystyky. Retrieved from: http://www.ukrstat.gov.ua/operativ/oper_new.html. [Główny Urząd Statystyczny. Retrieved from: https://stat.gov.pl/obszary-tematyczne/roczniki-statystyczne/ (accessed 27 June 2021).

22. Główny Urząd Statystyczny. Retrieved from: https://stat.gov.pl/obszary-tematyczne/roczniki-statystyczne/ (accessed 27 June 2021).

23. W 2020 r. przybyło lokali gastronomicznych. Retrieved from: https://www.horecatrends.pl/gastronomia/ 114/w_2020_r_przybylo_lokali_gastronomicznych,6513.html\#: :text=Z\%20czego\%20trwale\%20zbankrutowa\% C5\%820\%20i,si\%C4\%99\%20na\%2085\%2C5\%20tys (accessed 27 June 2021).

24. Tsentr prykladnykh doslidzhen. Vplyv Covid-19 na ekonomiku Ukrainy. Retrieved from: https://cpd.com.ua/ vplyv-COVID-19-na-ekonomiku-Ukrainy.pdf (accessed 26 June 2021).

25. Jaki wpływ na gastronomię może mieć koronawirus? Retrieved from: https://posbistro.com/blog/pl/jakiwplyw-na-gastronomie-moze-miec-koronawirus/ (accessed 27 June 2021). 